Research Paper

\title{
Travel to Southeast Asia: Learning About Southeast Asia through Augmented Reality
}

\section{Siti Zalifah Ramli ${ }^{1}$, Siti Aishah Zahari ${ }^{1}$, Nur Amalia Atikah Edyanto ${ }^{1}$, Muhammad Asyraf Abdullah Zawawi ${ }^{2}$, Nur Ain Najihah Ibharim ${ }^{1}$}

${ }^{1}$ Program of Software Engineering, Department of Computing. Faculty of Art, Computing and Creative Industry. Universiti Pendidikan Sultan Idris. Perak, Malaysia.

${ }^{2}$ Program of Information Technology (Education), Department of Computing. Faculty of Art, Computing and Creative Industry. Universiti Pendidikan Sultan Idris. Perak, Malaysia.

\author{
Article History \\ Received: \\ 22.08.2021 \\ Revised: \\ 14.09.2021 \\ Accepted: \\ 19.09.2021 \\ *Corresponding Author: \\ Siti Zalifah Ramli \\ Email: \\ jajaramli97@gmail.com
}

This is an open access article, licensed under: $\mathrm{CC}-\mathrm{BY}$-SA

\begin{abstract}
Travel to Southeast Asia' application is one of Augmented Reality (AR) technology. Learn about Southeast Asia is very important and has been emphasized in high schools. However, there are some students who are bored and not interested in learning geography especially related to foreign countries due to lack of exposure and information about it. So, the main purpose of this project is to develop an educational application based on Augmented Reality for students to interest them in learning about Southeast Asia. Students also can identify eleven countries in Southeast Asia by using this application and gain some knowledge related to the countries. Unity software is the main software to develop this Augmented Reality because Unity engine can support the high quality of audio and visual effects to ease the development of the project. This project developed by using ADDIE Model as a dynamic and flexible guideline for building effective training and performance support tools. This research was evaluated by among 15 students from Sultan Idris Education University who pursuing a Bachelor of Education (Geography) with Honor by using quantitative methods through online questionnaire. This questionnaire was distributed to the respondents for evaluation based on Usefulness, Satisfaction and Ease of Use (USE) questionnaire. As a result of the questionnaire, majority of respondents gave positive feedback and interested with 'Travel to Southeast Asia' application. Based on the research, learning about Southeast Asia using Augmented Reality provides better knowledge and understanding.
\end{abstract}

Keywords: Augmented Reality, Educational Technology, Geography Subject, Southeast Asia. 


\section{Introduction}

Nowadays, people can get a knowledge by using mobile phone since the usage of gadget is like a common thing, where the students are also using a mobile phone as one of the mediums for study to find information. As stated by Alphana et al [1] now the mobile phones are coming up with variety of features like internet access, sending emails, games, access to social networking sites, listening to the music, reading book and dictionary. So, teenagers especially students can use all the useful function of mobile phone for their studies. In addition, the usage of mobile phone in execution of the Pembelajaran dan Pemudahcaraan (PdPc, Teaching and Facilitation) will help them in terms of education in the 21st century. According O'Connor and Andrews [2], they found out that the usage of mobile phone benefited among student in better access to educational material, improvements in knowledge and confidence and reduced levels of anxiety learning in practice.

In this research, the use of mobile phones for PdPc and Augmented Reality is applied in the teaching and learning process (PdPc) in computing subjects [3] [4] [5], history [6] [7], and language [8]. This research proposes an Augmented Reality used in geography subject, especially in topic of Southeast Asia (or, Southeastern Asia). The application called "Travel to Southeast". There are some students who are bored and not interested in learning about other countries. This is because students are lack of exposed and knowledge about it. Students also did not like to learn about other countries because they feel difficult to imagine how the country look like. In addition, teaching and learning today is still in traditional method which is using text book as a reference material. One way that is used to overcome this problem is to apply Augmented Reality technology in PdPc.

\section{Literature Review}

\subsection{Augmented Reality}

Augmented reality (AR) is one of the biggest technology trends right now and it is only going to get bigger as AR ready smartphones and other devices become more accessible around the world. Silva et al [9] stated that augmented reality is a new technology that involves the overlay of the computer graphics on the real world. Augmented reality does not create the whole artificial environments, it just add sounds, videos and graphics to it.

According to Farshid et al [10], augmented reality refers to the integration of the actual world with digital information about it. It makes the real time environment merged with the digital content that is being generated by computer software simultaneously. Augmented reality is a breakthrough technology that could considerably ease execution of complex operations. Augmented reality mixes the virtual and actual reality, making available to the user new tools to ensure efficiency in the transfer of knowledge for several processes and in several environments.

\subsection{Augmented Reality Technology as a Learning Tool}

Augmented Reality in education will soon affect the conventional learning process. It has the potential to change the location and timing of studying, to introduce new and additional ways and methods. The use of augmented reality has become more accessible as it no longer requires specialised equipment and may easily be used on mobile devices [11].

Usually, students are inattentive in class because they are bored with the traditional ways of teaching. As we can see, the student engagement is dropping each year because institutes focus on standardized modes of teaching. Thus, use augmented reality in education will interest them to learn because students will remember better about they see instead about they listen or mug up. With augmented reality technology, a view of 3D is helping the students to understand better. Based on Khan et al. [11] the skills and knowledge that students develop through technology-enhanced learning environments may be developed more effectively through augmented reality technology.

\subsection{Mobile Phone as a Medium in Learning}

Nowadays, $80 \%$ of young people own mobile phones. Most of them are active mobile phone users that use these gadgets to access social platform, play games and to be in connection with friends and relatives. In the meantime, much lesser part of young adults uses mobile phone for studying purposes, to do the homework and search an information about the subjects. A number of research provide proof to the efficiency of M-learning courses, an example is the university in Brunel, which investigated the effects of mobile phones on learners during lesson and the level of their impact on mathematical skills development; the results are encouraging showing positive outcomes [12]. 
Mobile phone can be connected to internet at any time and at any place which is advantageous to students to browse anything through it related to their studies such as they can use the internet to download e-books, PowerPoint presentations and other materials and also give quizzes. According to Nsisong A. Udoh (2015), mobile phone theoretically make learner-centered learning possible by enabling students to customize the transfer of and access to information in order to build on their skills and knowledge and to meet their own educational goals.

\subsection{Motivation in the Context of Learning: Intrinsic Motivation Theory}

Motivation provides a source of energy that is responsible for why learners decide to make an effort, how long they are willing to sustain an activity, how hard they are going to pursue and how connected they feel to the activity [13]. Motivation is necessary for students to make an effort towards learning and to increase academic performance, as motivation plays an important role in the learning process.

Intrinsic motivation is the act of doing something without any obvious external rewards. Usually, they simply enjoy an activity or see it as an opportunity to explore, learn and actualize our potentials. The intrinsic motivation refers to engagement in behavior that is inherently satisfying or enjoyable. Intrinsic motivation is noninstrumental in nature, that is intrinsically motivated action is not contingent upon any outcome separable from the behavior itself. The challenge, curiosity, control and fantasy are the key factors to trigger up intrinsic motivation.

\subsection{Study of Existing Application}

Augmented Reality applications in learning about the location:

1. Asia Map Application

Asia Map application shows a map with almost 1700 provinces from Asia and parts of Africa and Europe with flag. The application is ideal for learning and playing. When user zoom in the map, then it will display the flag of the country and the name of the province. This application will make it easier for users to know the position of each province.

2. Pocket Malaysia

Pocket Malaysia is an augmented reality application to learn about the states in Malaysia. In this application, user can recognize the name of states in Malaysia, location of states in Malaysia map and other details regarding each state in Malaysia [6]. The Pocket Malaysia application is suitable as one of the technologies to learn about Malaysia for Form 1 students in Geography subject. By using this technology in the classroom, teachers can attract the attention of students.

\section{Methodology}

\subsection{Research Design}

This research uses quantitative method through questionnaire. The questionnaire was distributed to the respondents for evaluation based on Usefulness, Satisfaction and Ease of Use (USE) questionnaire. According to the journal from Gao et al [14], the Usefulness, Satisfaction and Ease of Use (USE) questionnaire measures the subjective usability of product or service. Usability questionnaires are used to collect self-reported data from users regarding their experience with a specific product and system. These questionnaires help researcher understand the usability of a product by revealing users' perception of outcomes and interactions. This method used to evaluate students' knowledge of Southeast Asia. This research was evaluated by among 15 students from Sultan Idris Education University who pursuing a Bachelor of Education (Geography) with Honor to get answers for all the questions in the questionnaire. The data then analyzed by descriptive statistics technique.

\subsection{Flowchart of the System Design and Development Process}

Figure 1 shows the flowchart of the project design to develop the application. Researcher identify the Southeast Asia topic based on Geography subject in Form 1. Researcher has determined to create about the position of countries and the tourist spot in Southeast Asia. For the interface design, researcher used the Microsoft PowerPoint and build the application into the android platform by using the Android SDK.

\subsection{Software Development Methodology}

The chosen software development methodology is ADDIE Model as shown in Figure 1. This model 
selected because the project that will be developed is educational application. ADDIE Model is an instructional design methodology used for technology- based teaching. The use of ADDIE model is that it is extremely valuable for large and complex teaching design. This model is a structured and continuous approach.

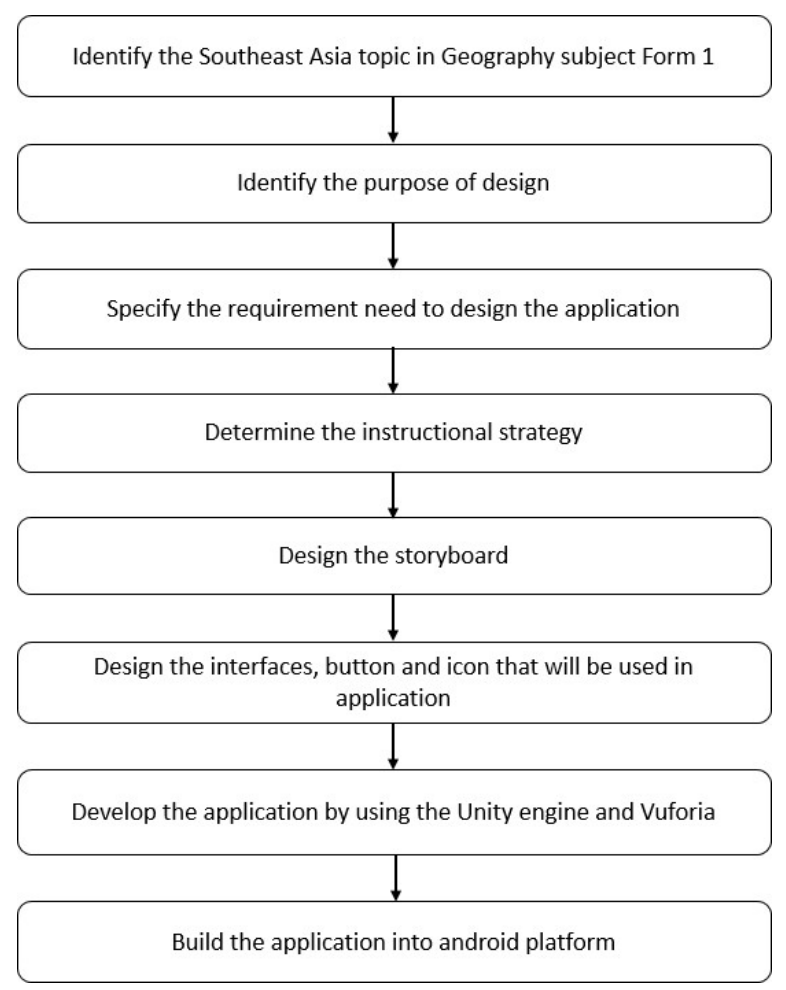

Figure 1. Flowchart of Travel to Southeast Asia application

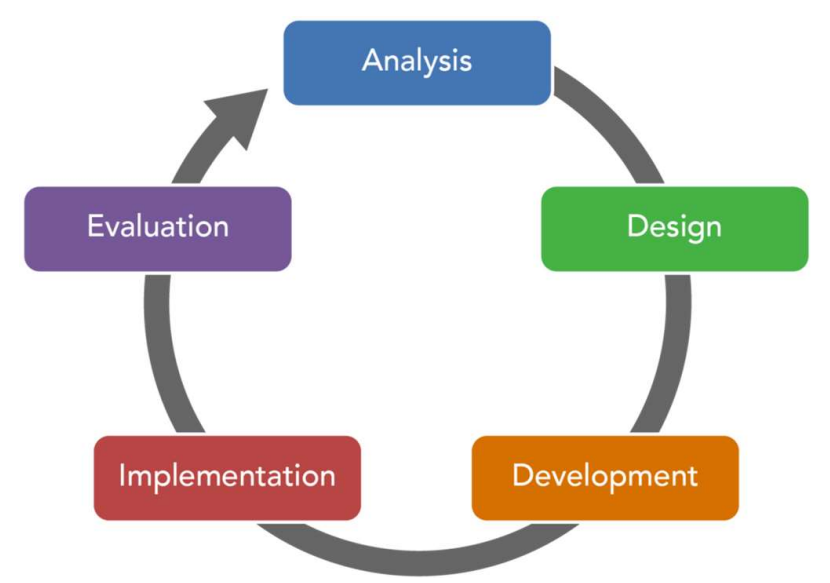

Figure 2. ADDIE Model

ADDIE is an acronym for the five stages of a development process which is Analysis, Design, Development, Implementation and Evaluation. The ADDIE Model relies on each stage being done in the given order but with a focus on reflection and iteration. ADDIE model used in developing an information system [15] [16], tracking and monitoring [19] even for decision system [20]. 


\subsection{System Requirement}

There are two types of system requirements, which is hardware requirement and software requirement.

\subsubsection{Hardware Requirement}

The hardware needed to develop an Augmented Reality application are:

Central Processing Unit (CPU) with processor : Intel Core i7 or above or AMD equivalent or above.

Random Access Memory (RAM)

Graphic

: 8GB DDR3 memory or above

Storage

: NVIDIA GeForce GTX 770M with 3GB DDR3

Display

VRAM or above or ATI/AMD equivalent or above

Input

Free space of 50GB or above

: 14.0" $16: 9 \mathrm{HD}(1366 \times 768)$ or above

: Built-in or external webcam

\subsubsection{Software Requirement}

The software needed to develop an Augmented Reality application are:

Computer operating system : Windows 7 or above.

AR development toolkit : Unity3D, Vuforia and Visual Studio.

Designing AR marker : : Adobe Photoshop.

\subsection{Evaluation}

Feedback from the respondents collected by using online questionnaire via google form. The questionnaire was evaluated by 15 students from Sultan Idris Education University who are pursuing in Bachelor of Education (Geography) with Honor.

The questionnaire is based on Usefulness, Satisfaction, and Ease of Use (USE) questionnaire. Respondents need to answer the questionnaire based on Likert Scale to measuring all the questionnaire items. The Likert Scale consists of strongly disagree, disagree, undecided, agree and strongly agree. For the result, researcher analyzed the data in percentage and has been shown in the form of a bar chart.

\section{Result}

\subsection{Marker}

For the AR marker, researcher used transparent images of Southeast Asia map which is downloaded from the internet. Then, the map of Southeast Asia will be separated from each other and saved it in Joint Photographic Experts Group (JPG) format. Once finished, the map saved in Vuforia as the target marker.

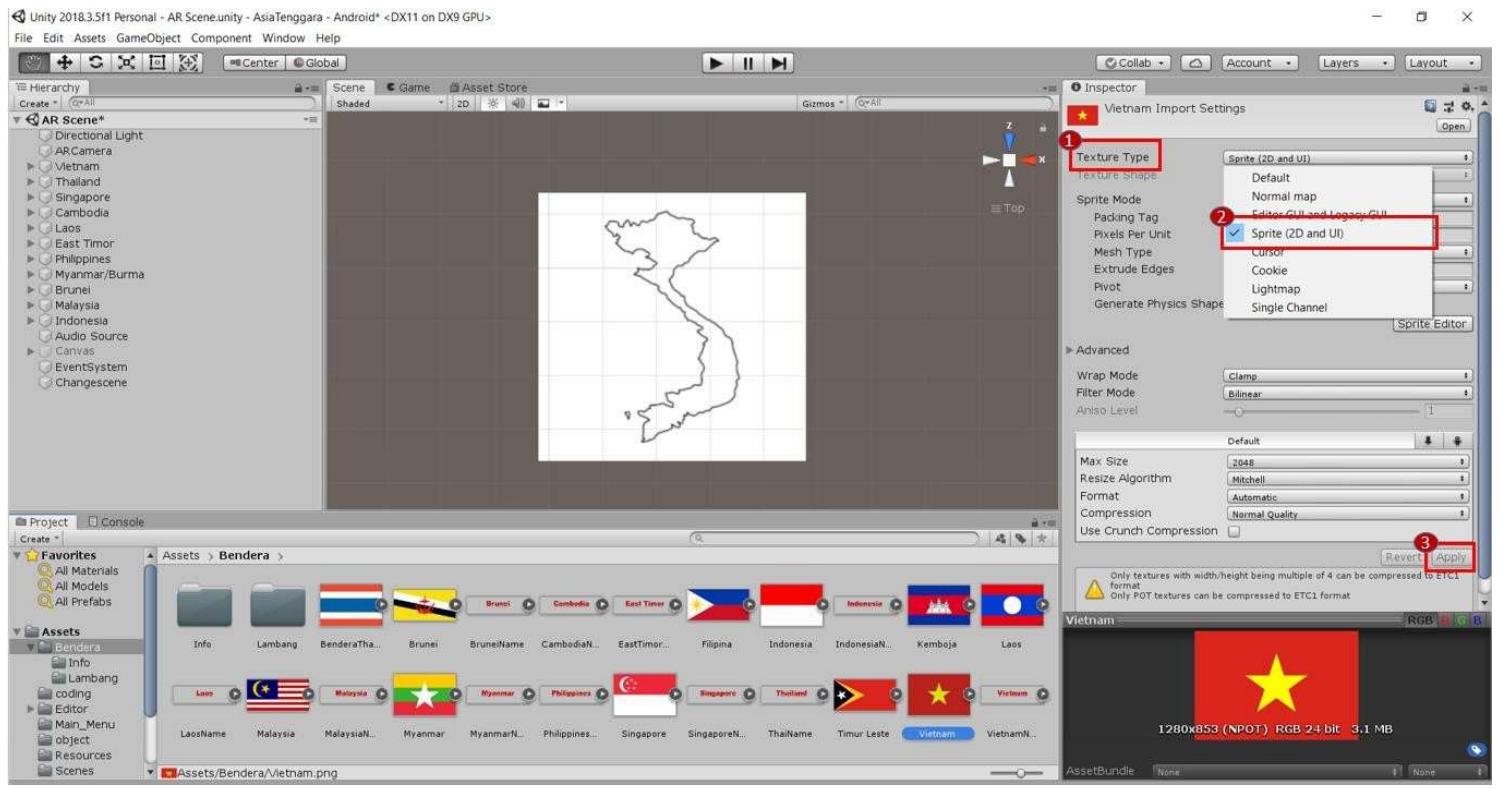

Figure 3. AR Marker Based for the "Travel to Southeast Asia" Application 


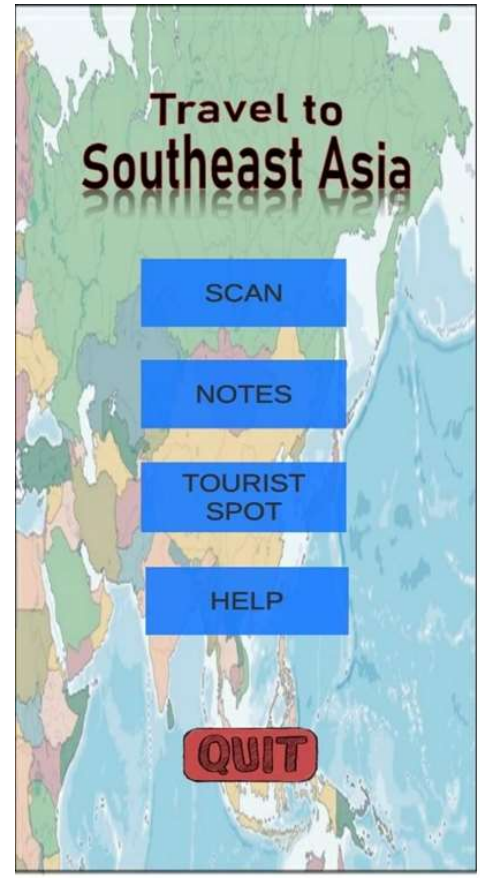

(a)

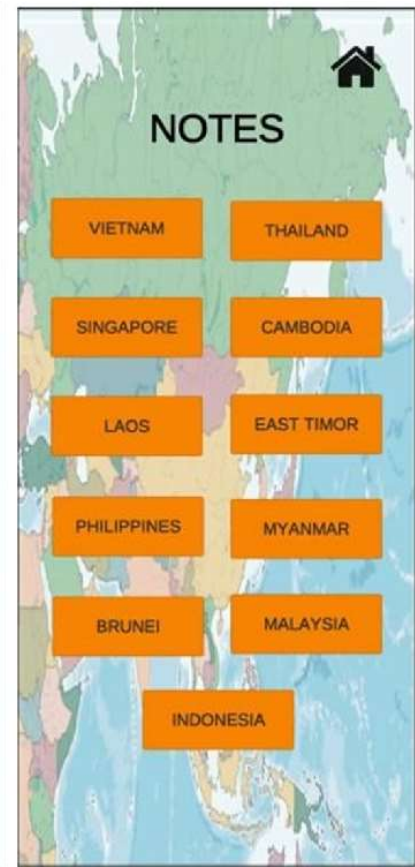

(b)

Figure 4. Interface for "Travel to Southeast Asia" Application

(a) Main Menu

(b) Notes

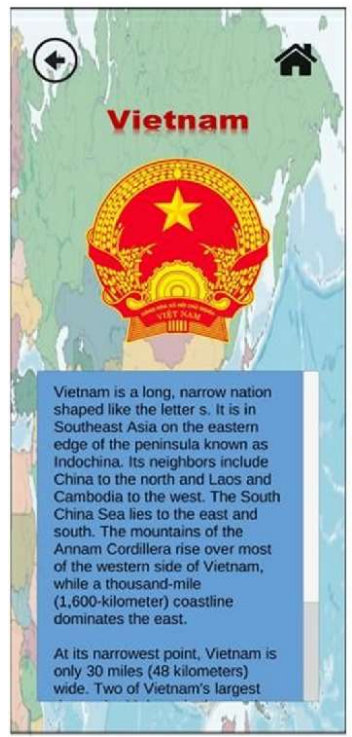

(a)

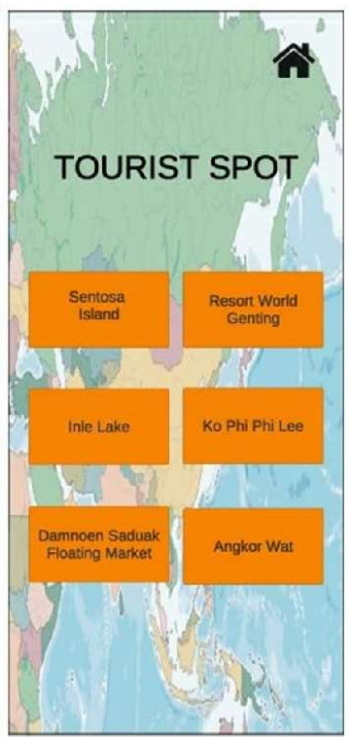

(b)

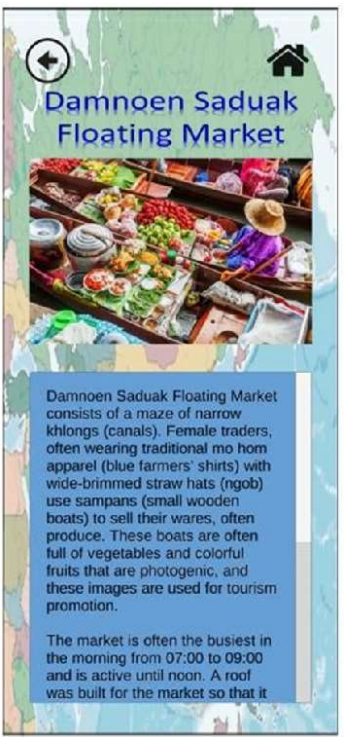

(c)

Figure 5. Interface for Vietnam page

(a) Information about Vietnam

(b) Tourist Spot in Vietnam

(c) Information about a Tourist Spot 


\subsection{Interface}

Figure 4 shows the main menu for "Travel to Southeast Asia" application. The Main Menu is the main menu for "Travel to Southeast Asia" application that display a menu containing the button that expose functionality related to the application such as 'Scan', 'Notes', 'Tourist Spot', 'Help' and 'Quit' button. The 'Notes' is the sub-menu for Travel to Southeast Asia application that display a menu containing button that provide an option to get content of notes to recognize all about the countries in Southeast Asia.

\subsection{Repondent Feedback}

\subsubsection{Demography}

Based on Figure 6, the number of male respondents is lower than female respondents with $26.7 \%$ and female respondents with $73.3 \%$. All 15 respondents are Degree students who pursuing a Bachelor of Education (Geography) with Honor in Sultan Idris Education University (UPSI).

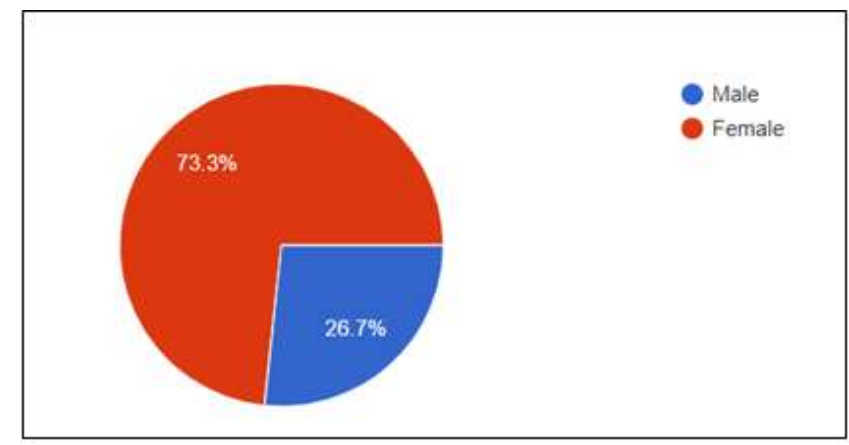

Figure 6. Respondent Demographic Information based on Gender

Figure 7 shows that the majority of students who have responded in this evaluation are from Semester 7 with $53.3 \%$ followed by students from Semester 6 with $40 \%$ and Semester 4 with $6.7 \%$.

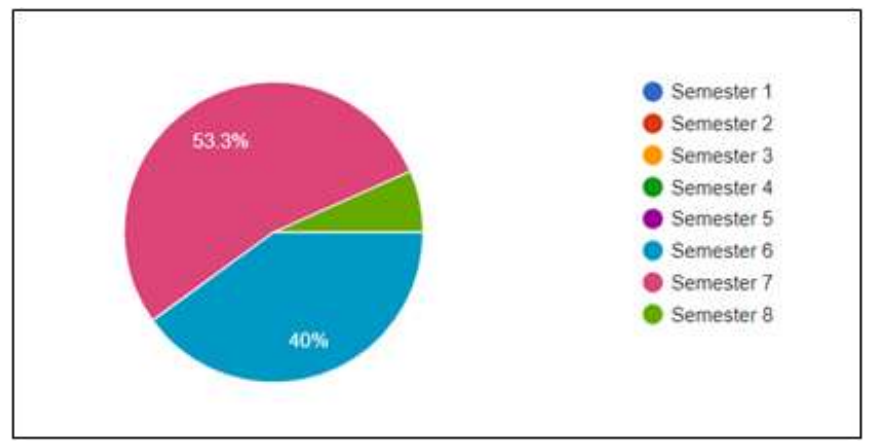

Figure 7. Respondent Demographic Information based on Semester

\subsubsection{Usefulness}

In this questionnaire section, six questions has been evaluated by all 15 respondents which is about the usefulness of Travel to Southeast Asia application. According to the Figure 8, question 1 is about the application helps user to be more effective. There are $8(53 \%)$ respondents have strongly agreed and 6 $(40 \%)$ respondents were agreed at this statement. While, only $1(7 \%)$ respondent who was undecided about the statement.

For the question 2 , it is about the application helps user be more productive. (67\%) respondents were strongly agreed and (27\%) respondents were agreed about the statement. Meanwhile, there was $1(7 \%)$ respondent who was undecided. 
Question 3 is about the application is useful to user. There are 10 respondents with $67 \%$ were strongly agreed with the statement and only 5 respondents with $33 \%$ were agreed.

Question 4 is about the application meets users' needs. 8 (54\%) respondents were strongly agreed that Travel to Southeast Asia application meets their needs and $6(40 \%)$ respondents were agreed. There was $1(7 \%)$ respondent who was undecided.

Question 5 is about the Travel to Southeast Asia application helps user to gain knowledges about Southeast Asia. Based on the result, there are $10(67 \%)$ respondents were strongly agreed and $3(20 \%)$ respondents were agreed with the statement. Meanwhile, $2(13 \%)$ were undecided whether they can gain knowledge about Southeast Asia or not.

Question 6 is about the Travel to Southeast Asia application saves users' time when they use it. 9 $(60 \%)$ respondents were strongly agreed and $4(27 \%)$ respondents were agreed with the statement, but there are $2(13 \%)$ respondents were undecided.

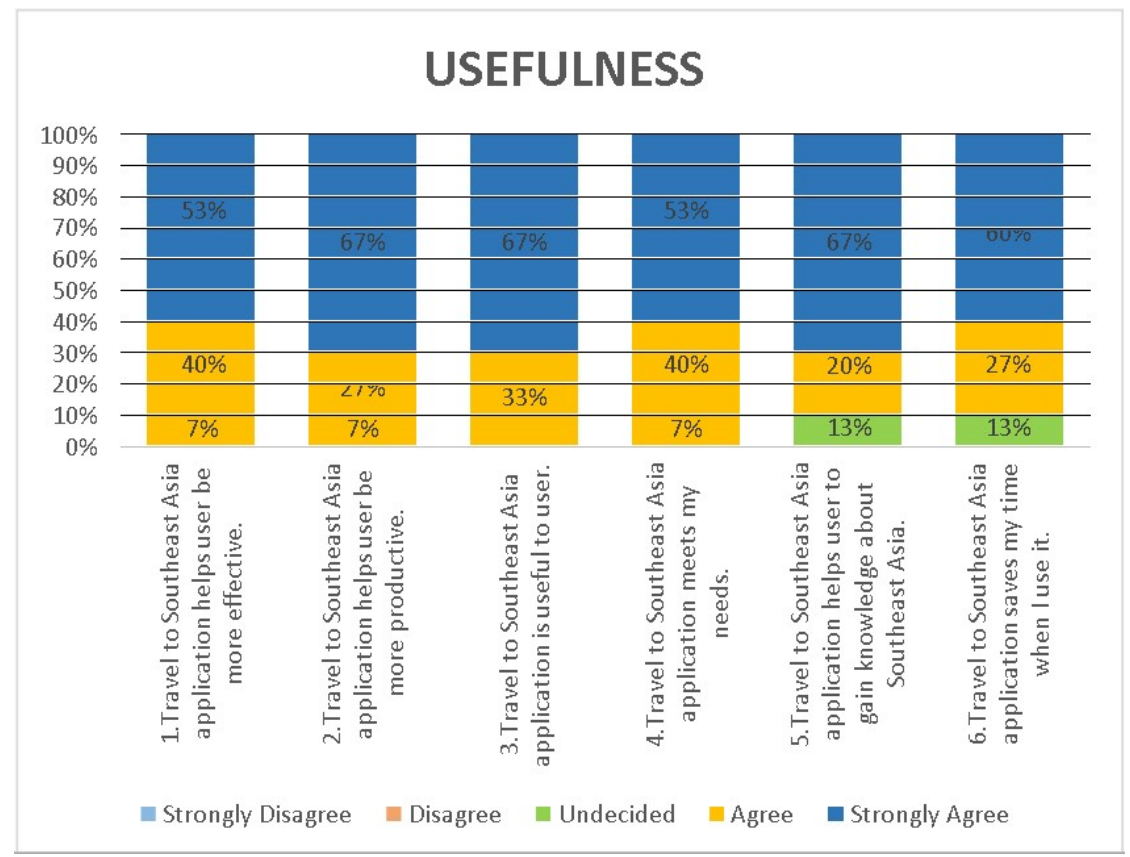

Figure 8. Usefulness

\subsubsection{Satisfaction}

In this questionnaire section, six questions has been evaluated by the respondents for question 7 until question 12. This questionnaire is about the satisfaction of the application. Based on Figure 9, question 7 related to the statement of users are satisfied with Travel to Southeast Asia application. There are 11 respondents with $73 \%$ were strongly agreed with the statement and just 4 respondents with $27 \%$ agreed about that.

Question 8 is about the users would recommend Travel to Southeast Asia application to their friends. In this statement, $8(53 \%)$ respondents were strongly agreed and $6(40 \%)$ respondents were agreed. Meanwhile, there is $1(7 \%)$ respondent was undecided.

Question 9 related to the statement of Travel to Southeast Asia application is pleasant to use. There are $9(60 \%)$ respondents were strongly agreed and $5(33 \%)$ respondents were agreed with this statement. Only $1(7 \%)$ respondent was undecided whether this application is pleasant to use or not.

Question 10 is about Travel to Southeast Asia application is wonderful. In this statement, there are $9(60 \%)$ respondents were strongly agreed while the rest of respondents $(40 \%)$ were agreed about that.

Question 11 related to the travel to Southeast Asia application works the way I want it to work. 10 $(67 \%)$ respondents were strongly agreed with the statement, $4(27 \%)$ respondents were agreed and the rest $(7 \%)$ was undecided.

Question 12 is about if the users feel they need to have Travel to Southeast Asia application in their 
mobile phone. There are $8(53 \%)$ respondents were strongly agreed and $5(33 \%)$ respondents were agreed with this statement. Only $2(13 \%)$ respondents were undecided.

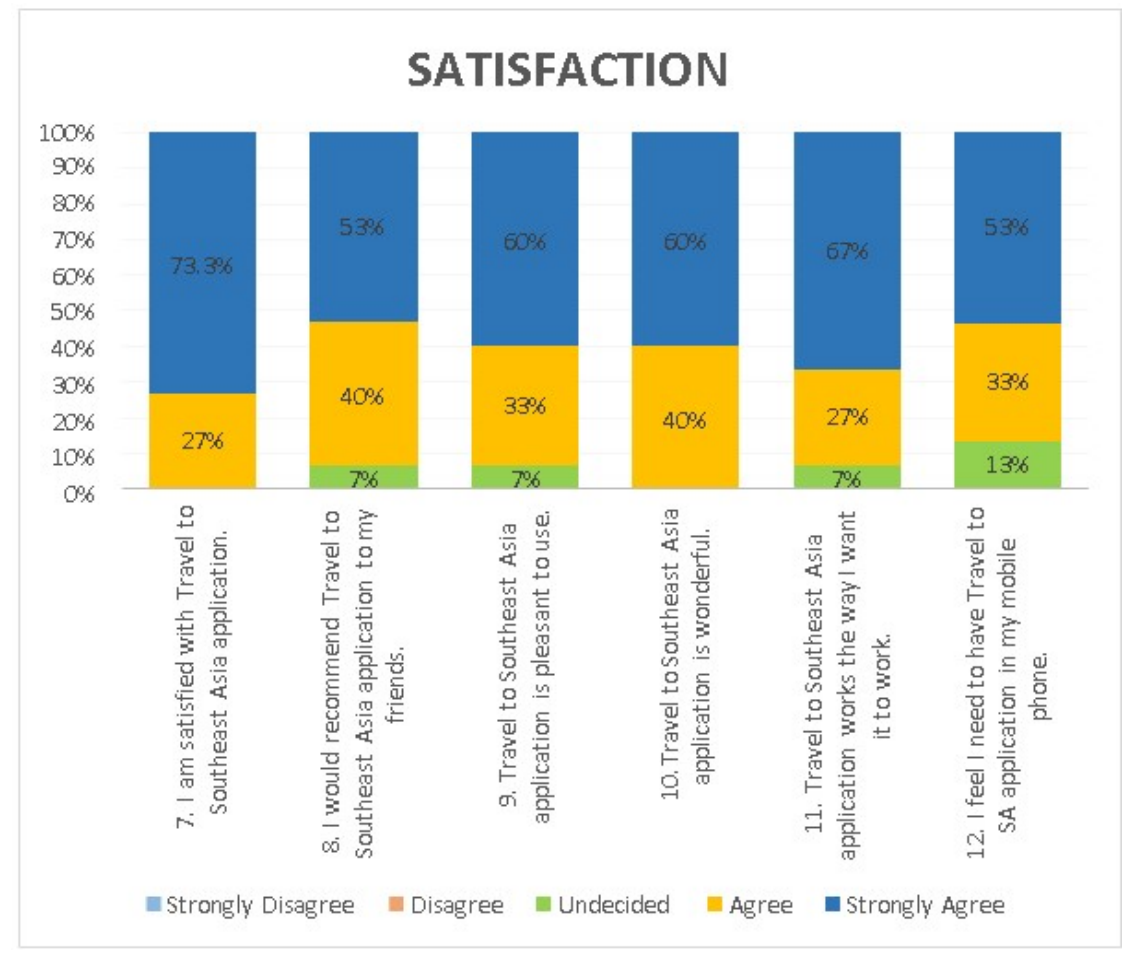

Figure 9. Satisfaction

\subsubsection{Ease of Use}

In this questionnaire section, there are six questions which is question 13 until question 18 that has been evaluated by the respondents. This section is about the ease of use of the application. According to the result shows in Figure 10, question 13 is related to the statement of Travel to Southeast Asia application is easy to use. There are $11(73 \%)$ respondents were strongly agreed and the rest of the respondents (27\%) were agreed with the statement.

Question 14 is about the Travel to Southeast Asia application is simple to use. $10(67 \%)$ respondents were strongly agreed and $4(27 \%)$ respondents were agreed with the statement. Meanwhile, there is 1 (7\%) respondent was undecided.

Question 15 is related to the statement of Travel to Southeast Asia application is user friendly. There are $9(60 \%)$ respondents were strongly agreed and the rest of the respondents $(40 \%)$ are agreed.

Question 16 is about the Travel to Southeast Asia application requires the fewest steps possible to accomplish what users want to do with it. $8(53 \%)$ respondents were strongly agreed and $6(40 \%)$ respondents were agreed with the statement. Meanwhile, there is $1(7 \%)$ respondent was undecided.

Question 17 is about the statement of users can use Travel to Southeast Asia application without written instructions. Majority respondents strongly agreed with the statement that is $10(67 \%)$ respondents and there is only $5(33 \%)$ respondents were agreed.

For the last question that is question 18 is about the statement of using Travel to Southeast Asia application is effortless. $9(60 \%)$ respondents were strongly agreed and $5(33 \%)$ respondents were agreed with the statement. Meanwhile, there is $1(7 \%)$ respondent was undecided whether the application is effortless or not. 


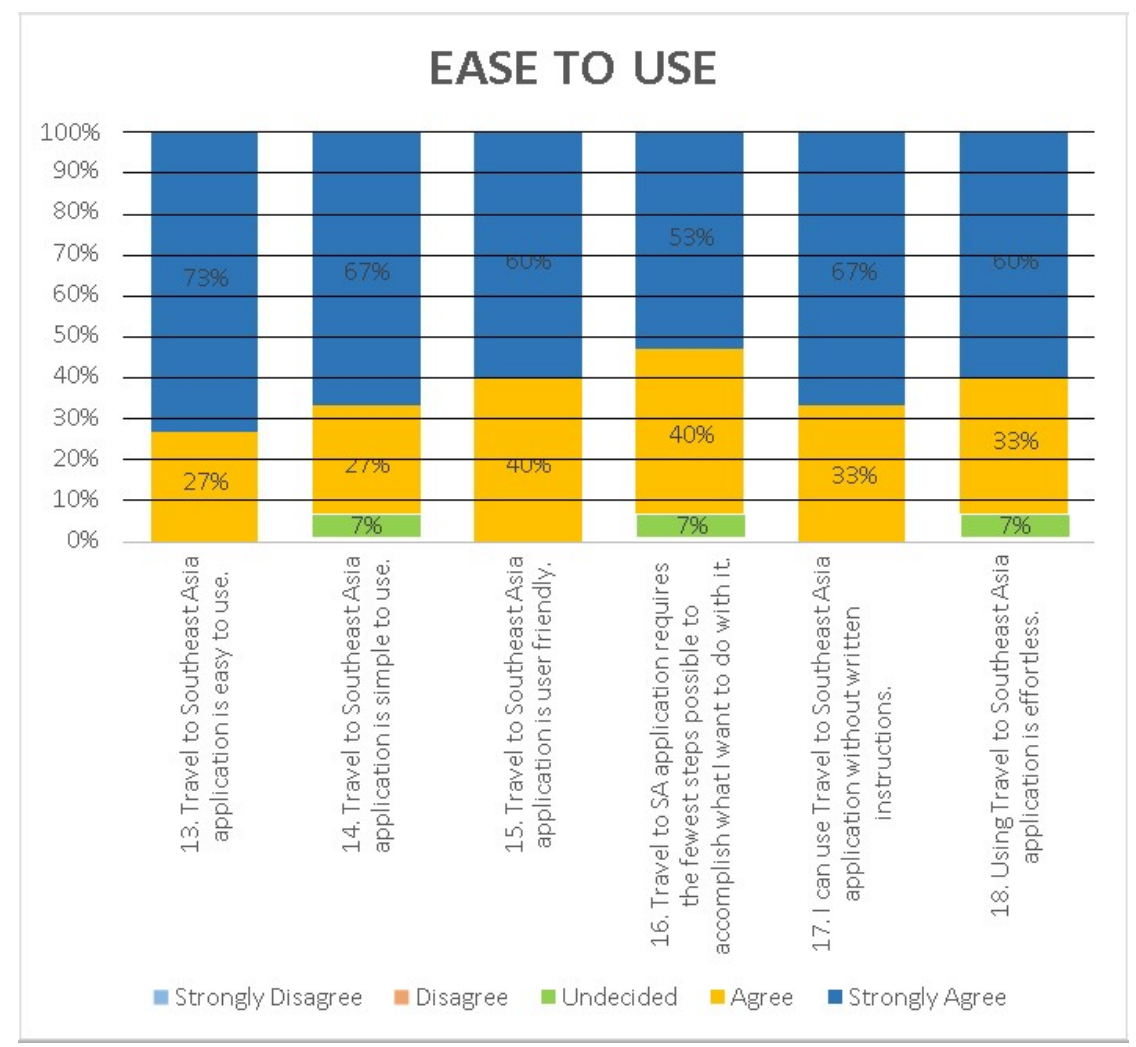

Figure 10. Easy of Use

Once the research has been done, researcher found that Travel to Southeast Asia application has a good reception in learning about Southeast Asia. Researcher analyzed the topics that are in Form One Geography textbook before starting the application development. This is because researcher want to make sure that the application is suitable to be applied with the augmented reality technology.

The first objective of this research is to develop an augmented reality application that can help students to identify eleven countries in Southeast Asia. With the function of 'Scan' button, students can know more about Southeast Asia by using augmented reality technology 2-Dimension shape of flag will be shown at the mobile phone screen and there was information related to the scanned map (marker) with its national anthem will be played.

Based on the repondent feedback, this application is suitable for students who are not interested in learning map and geography especially it is related to foreign countries. Travel to Southeast Asia application is an effective augmented reality technology that can used for teaching and learning process where several research has published in form of articles journal that described the augmented reality application use in the context of education.

\section{Conclusion}

This application exposed and given knowledgeable related to the countries located in Southeast Asia about the name of the country and its flag, location of the country in Southeast Asia map, the national anthem and the famous tourist spot in Southeast Asia. With the function of 'Notes' button, students can find out the existence of such countries in Southeast Asia. Students also can gain knowledge about the geographical of the area.

Based on the feedback received, the "Travel to Southeast Asia" application is an innovated tool in $\mathrm{PdPc}$ and be responsive to enhance the learning experience of the students. There are several things that need to be done to improve the performance of the "Travel to Southeast Asia" application, including:

1. The content of the application need to be improved such as the 2D image of tourist spot change to $3 \mathrm{D}$ image. For example, choose 1 historic building in the country that is a tourist attraction and make it as 3D image in the new augmented reality scene with a new target image. By doing 
this, students will be more interested in learning Southeast Asia.

2. The additional information in the application also could be improved such as add the history notes of eleven countries. Preferably, use a mind map or storytelling to explain the history of the countries. With that, students can better understand and remember it easily.

3. Travel to Southeast Asia also can be deployed for IOS platform instead of Android platform so that it is not limited to Android users. As we know, the number of iOS users is increasing among the current generation. By implementing this application in iOS platform, iOS users can install and run it in their mobile phone. Thus, this improvement can attract more user to use it.

\section{References}

[1] V. Alpana, P. Vinayak, and V. Ajay, "Mobile Phone Usage among Youth", International Journal of Applied Research and Studies, vol. 5, no. 3, 2016.

[2] S. O'Connor and T. Andrews, "Nursing Students' Opinion on the Use of Smartphone Applications (Apps) in Clinical Education and Training: A Study Protocol," Stud Health Technol Inform, vol. 225, pp. 1024-1025, 2016.

[3] N. H. Rahani, A. A. Bilong, M. R. Mat Suruji, and I. Y. Panessai, "Learning Logic Gates Using Augmented Reality", International Journal of Multimedia and Recent Innovation, vol. 2, no. 1, pp. 26-44, Mar. 2020.

[4] Z. Zainal Abidin and M. A. Abdullah Zawawi, "OOP-AR: Learn Object Oriented Programming Using Augmented Reality”, International Journal of Multimedia and Recent Innovation, vol. 2, no. 1, pp. 60-75, Mar. 2020.

[5] S. N. S. Abu Samah, "The Efficacy of Augmented Reality on Student Achievement and Perception among Teluk Intan Community College Student in Learning 3D Animation", International Journal of Multimedia and Recent Innovation, vol. 2, no. 2, pp. 87-95, Sep. 2020.

[6] S. F. Sezali, A. M. Radzuan, N. I. Mohd Shabudin, and R. A. Afendi, "POCKET MALAYSIA: Learning About States in Malaysia Using Augmented Reality", International Journal of Multimedia and Recent Innovation, vol. 2, no. 1, pp. 45-59, Mar. 2020.

[7] N. A. N. Ibharim, S. Z. Ramli, S. A. Zahari, N. A. A. Edyanto, and M. A. Abdullah Zawawi, "Learning History Using Augmented Reality", International Journal of Multimedia and Recent Innovation, vol. 3, no. 1, pp. 1-10, Mar. 2021.

[8] N. A. A. Edyanto, S. Z. Ramli, N. A. N. Ibharim, S. A. Zahari, and M. A. Abdullah Zawawi, "Learn Idioms Using Augmented Reality", International Journal of Multimedia and Recent Innovation, vol. 3, no. 1, pp. 11-16, Mar. 2021.

[9] R. Silva, J. C. Oliveira, G. A. Giraldi, "Introduction to Augmented Reality," 2001. [Online]. Available: https://members.aixr.org/storage/RelatorioTecnicoLNCC-2503.pdf. [Accessed: February, 2021].

[10] M. Farshid, J. Paschen, T. Eriksson, and J. Kietzmann, "Go boldly!: Explore Augmented Reality (AR), Virtual Reality (VR), and Mixed Reality (MR) for Business," Business Horizons, vol 61, no. 5, pp.657-663, 2018.

[11] T. Khan, K. Johnston and J. Ophoff, "The Impact of an Augmented Reality Application on Learning Motivation of Students," 2019. [Online]. Available: https://dl.acm.org/doi/10.1155/ 2019/7208494. [Accessed: February, 2021].

[12] A. A. Aish, S. Love and Z. Hunaiti, "Mathematics Students' Readiness for Mobile Learning," International Journal of Mobile and Blended Learning (IJMBL), vol. 4, no. 4, pp. 1-20, 2012.

[13] I. María, D. S. Angela, V. Diego, D. K. Carlos, "Augmented Reality-Based Simulators as Discovery Learning Tools: An Empirical Study," IEEE Transactions on Education, vol 5, no. 8, 2015.

[14] M. Gao, P. Kortum and F. Oswald, "Psychometric Evaluation of the USE (Usefulness, Satisfaction, and Ease of use) Questionnaire for Reliability and Validity," Proceedings of the Human Factors and Ergonomics Society Annual Meeting, vol. 62, no. 1, pp. 1414-1418, 2018.

[15] Suganda, R. D. Permatasari, Pratiwi, and I. Y. Panessai, "Sistem Informasi Pemantauan Retribusi Pada Menara Telekomunikasi”, International Journal of Education, Science, Technology, and Engineering, vol. 2, no. 2, pp. 97-111, Dec. 2019. 
[16] Anwar and J. Riyanto, "Perancangan Sistem Informasi Human Resources Development Pada PT. Semacom Integrated", International Journal of Education, Science, Technology, and Engineering, vol. 2, no. 1, pp. 19-38, Jun. 2019.

[17] N. F. Z. Zakaria, Z. Zainal Abidin, M. A. Abdullah Zawawi, and S. N. Shuhada, "Bloodbuddy: a Tracking System for Blood Donor Using GPS", Journal of Engineering, Technology, and Applied Science, vol. 2, no. 2, pp. 86-102, Aug. 2020.

[18] M. Olva, R. Dwiputri Permatasari, S. Majid, P. Syair, and A. Suganda, "Pemanfaatan Dasbor pada Pemantauan Data Transaksi Penjualan", Journal of Engineering, Technology, and Applied Science, vol. 3, no. 1, pp. 1-15, Apr. 2021.

[19] F. Duwiyanti and M. Ardhiansyah, "Sistem Pendukung Keputusan Pemilihan Guru Terbaik di SMK Pustek Serpong", International Journal of Education, Science, Technology, and Engineering, vol. 2, no. 1, pp. 45-67, Jun. 2019.

[20] S. Apandi, O. Veza, S. Majid, and P. Pratiwi, "Penentuan Bonus Karyawan dengan Menggunakan Metode Analytic Network Process di PT. Global Harvest Precision Engineering", Journal of Engineering, Technology, and Applied Science, vol. 2, no. 1, pp. 51-58, Apr. 2020. 